\title{
"NEW KIDS ON THE BLOCK" - THE GAME CHANGERS. THE ROLE OF IMMUNE CHECK POINT BLOCKADE IN PERSONALISED TREATMENT OF PROSTATE, URINARY BLADDER AND KIDNEY CANCER
}

\author{
Kristofs Folkmanis ${ }^{1,2, \#}$, Elizabete Junk ${ }^{1,2}$, Evelīna Merdane ${ }^{1}$, Valdis Folkmanis ${ }^{1}$, \\ Inese Folkmane ${ }^{1}$, and Sergejs Isajevs ${ }^{1,3}$

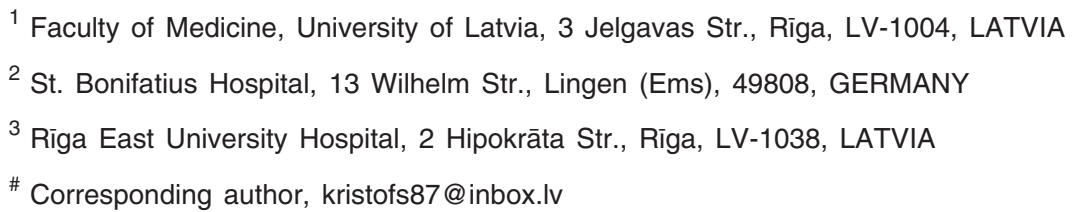

Communicated by Ingrīda Rumba-Rozenfelde

\begin{abstract}
Early detection and diagnosis of cancer followed by a personalised approach to treatment is a key and can save lives. It has been an important issue in both the medical and social fields. The search for instruments and/or diagnostics tools able to detect cancers at an early stage has led to consideration of the usage of various approaches, such as exhaled air, biomarkers in blood, urine testing as well as imaging techniques. This actual time and everything that is happening around us could be characterised as a strange and very unpredictable time. This comparison could be made not only due to the actual coronavirus situation, but also the same can be noticed in the personalised medicine of the second decade of 21st century - by means of check point inhibitors. The old dogmas, for instance, chemotherapy and metastasis-surgery are being appended with new diagnostic and therapy use of checkpoint inhibitors. What exactly is the checkpoint blockade and how it is working in three tumour modalities: bladder cancer, prostate cancer and renal cancer. Our study group will provide a brief and detailed, guideline-compliant outline. The aim of this review was to provide a summary of the current state of the art of immune therapy as potential treatment of prostate, urinary bladder, and kidney cancer.
\end{abstract}

Key words: checkpoint inhibitors, $P D-L 1 / P D-1$ expression, DNS mismatch repair deficiency, microsatellite instability, tumour mutational burden.

\section{BRIEF HISTORY OF CHECKPOINT INHIBITORS}

Immune checkpoints are a normal part of the immune system, which prevent an immune response from being so strong that it destroys healthy cells in the body. However, they can be used by cancer cells to "hide" the tumour from immune cells (specifically, T cells) and prevent the immune system from destroying the cancer (Pardoll, 2012).

Checkpoint inhibitor therapy is a form of cancer immunotherapy. The therapy targets immune checkpoints, key regulators of the immune system that when stimulated can dampen the immune response to an immunologic stimulus. Some cancers can protect themselves from the attack by stimulating immune checkpoint targets. Checkpoint therapy can block inhibitory checkpoints, restoring immune system function (Pardoll, 2012).

The first anti-cancer drug targeting an immune checkpoint was ipilimumab, a CTLA4 blocker approved in the United States in 2011 (Cameron et al., 2011).

Currently approved checkpoint inhibitors target the molecules CTLA4, PD-1, and PD-L1.

PD-1 is the transmembrane programmed cell death 1 protein (also called PDCD1 and CD279), which interacts with PD-L1 (PD-1 ligand 1, or CD274). PD-L1 on the cell surface binds to PD1 on an immune cell surface, which inhibits immune cell activity. Among PD-L1 functions is a key 
regulatory role on T cell activities (Butte et al., 2007; Karwacz et al., 2011).

The programmed death (PD)-1 receptor-PD-1ligand (PDL1) interaction is a key immune checkpoint that is overridden by malignant tumours to escape from the immune surveillance.

It appears that (cancer-mediated) upregulation of PD-L1 on the cell surface may inhibit $\mathrm{T}$ cells that might otherwise attack. Antibodies that bind to either PD-1 or PD-L1 and therefore block the interaction may allow the T-cells to attack the tumour (Syn et al., 2017).

Immunotherapy comprises a promising new era in cancer therapy. Immune checkpoint inhibitors targeting either the programmed death (PD)-1 receptor or its ligand PD-L1 were first approved by the Food and Drug Administration (FDA) for the management of metastatic melanoma in 2011.

The discoveries in basic science allowing checkpoint inhibitor therapies led to James P. Allison and Tasuku Honjo winning the Tang Prize in Biopharmaceutical Science and the Nobel Prize of Physiology or Medicine in 2018 (Devlin, 2018).

\section{ROLE OF CHECKPOINT BLOCKADE IN BLADDER CANCER}

Actual urology guidelines (year 2020) in terms of using checkpoint blockade in an oncological medicinal setting have significant impact on bladder cancer treatment (Witjes et al., 2020). Systemic therapy for urothelial carcinoma of the urinary bladder is used either perioperatively with curative intent for cystectomy (neoadjuvant / inductive or adjuvant) or as palliative chemotherapy. Currently, only chemotherapy is considered as a system therapy for perioperative use. Chemotherapy and immunotherapies are available for metastatic bladder carcinoma (Witjes et al., 2020).

The inclusion criteria of patient's compliance for chemotherapy containing cisplatin, which depend on various factors like performance status and renal function (Fig. 1), are decisive for the selection of system therapy. In the case of appropriate renal function and performance status (PS 0-1 and GFR $\geq 60 \mathrm{ml} / \mathrm{min}$ ) there is the option to apply chemotherapy, for example, a cisplatin based one. If the glomerular filtration rate (GFR) is $<60 \mathrm{ml} / \mathrm{min}$ and $\mathrm{PS} \geq 2$, cisplatin should no longer be used, and in this scenario immune blockade enters the first line setting in the therapy course. In the second line setting, the place of immune blockade is already granted (Fig. 1) (Witjes et al., 2020).

Regarding chemotherapy, the effectiveness of gemcitabine/ cisplatin (Gem/Cis) and methotrexate/vinblastine/adriamycin/cisplatin (MVAC) is considered to be equivalent (Maase, 2005). The response (49\% vs. 46\%) and overall survival (13.8 vs. 14.8 months) were not significantly different. From a statistical point of view, however, the study was planned as a superiority study, so that the primary endpoint was not achieved. Formally, therefore, it cannot be concluded from the study that $\mathrm{Gem} / \mathrm{Cis}$ is as effective as MVAC. However, this aspect is neglected in everyday clinical practice due to the more favourable toxicity profile and $\mathrm{Gem} / \mathrm{Cis}$ is regarded as the standard (Eisenhardt et al., 2020).

As an alternative to carboplatin-based chemotherapy, immunotherapy with pembrolizumab or atezolizumab is available for patients who are not eligible for cisplatin-based chemotherapy (Witjes et al., 2020).

However, a prerequisite for the use of immunotherapy is that the patient has a positive PD-L1 status. For pembrolizumab, the positive PD-L1 status ("programmed cell death ligand 1") is defined as a CPS ("combined positive score") of $\geq 10 \%$. For the CPS, the number of PD-L1-positive tumour and immune cells in the tumour material is divided by the total number of vital tumour cells $\times 100$. In contrast, an IC (immune cell) of $\geq 5 \%$ is required for therapy with atezolizumab. Only the PD-L1 expression of the tumour-infiltrating immune cells in the tumour material is evaluated here. Ideally, both scores are determined to allow a free choice of therapy. In individual cases, the score may not be sufficient for one therapy, but meet the cut-off for the other substance. The analysis is done immunohistochemically and should be able to be performed by every pathologist after appropriate training (Eisenhardt et al., 2020).

The evidence on the first-line use of immunotherapy in cisplatin-unsuitable patients is generated from two phase II studies. In the IMvigor210 study, atezolizumab showed a response rate of $23 \%$, independent of PD-L1 expression (Balar, 2017). More recent studies, however, showed a connection between the effectiveness and PD-L1 expression with an advantage in patients with high PD-L1 expression: IMvigor130 study (Grance et al., 2019).

Results from the KEYNOTE 052 study are available for pembrolizumab, which describe a response rate of $24 \%$ (Falkmer et al., 2003). In an interim evaluation of the KEYNOTE 361 study as a phase III study in first-line therapy, a relationship between PD-L1 expression (CPS score) and patient survival was reported, such that pembrolizumab was approved for patients with high PD-L1 expression (Witjes et al., 2020).

In the event of progression after first-line therapy, immunotherapy with pembrolizumab should be carried out; alternatively, atezolizumab or nivolumab can be used. The difference in the level of recommendation is due to the level of evidence, since data from a phase III study are only available for pembrolizumab (Witjes et al., 2020).

The KEYNOTE-045 study compared pembrolizumab versus chemotherapy (vinflunine or taxanes) and showed a survival advantage of 10.3 vs. 7.4 months, respectively (Bellmunt, 2017). The response was $21.1 \%$. In this study, also, there was a connection between PD-L1 expression and ef- 


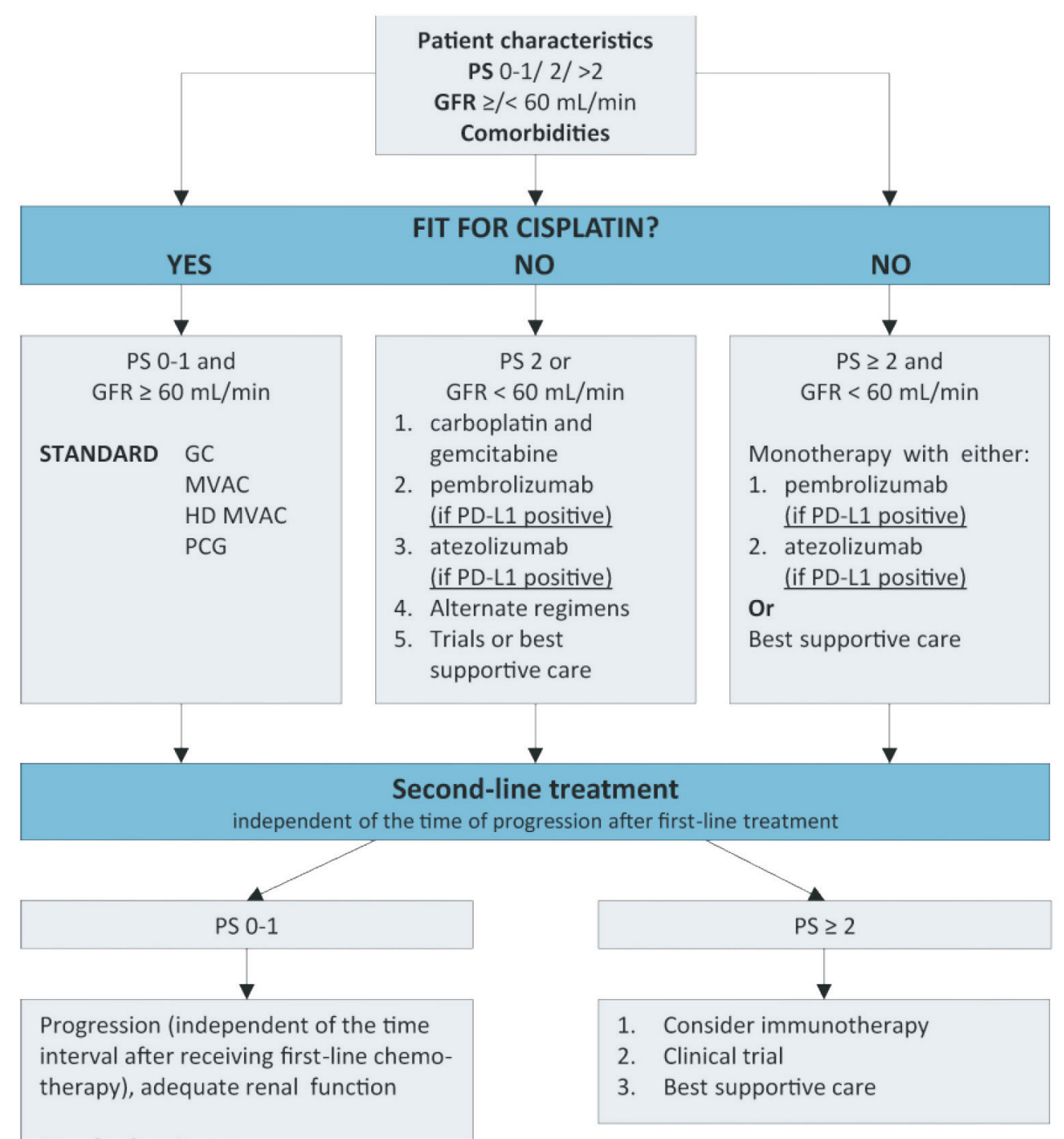

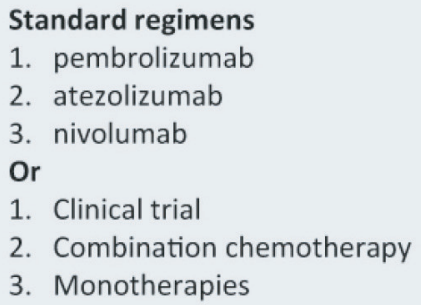

fectiveness, which, however, did not lead to a restriction in approval, and it showed also a good toxicity profile of pembrolizumab compared to chemotherapy.

Data from phase II studies are available for atezolizumab and nivolumab. Atezolizumab showed a response of $15 \%$ with an overall survival of 7.9 months (Balar, 2017). Nivolumab achieved a response of $19.6 \%$ and an overall survival of 8.7 months in the ChackMate-275 study (Sharma, 2017).
Fig. 1. Therapy algorithm for systemic therapy of urothelial carcinoma of the urinary bladder. GC, gemcitabine plus cisplatin; GFR, glomular filtration rate; HD-MVAC, (high-dose) methotrexate, vinblastine, adriamycin plus cisplatin; PCG, paclitaxel, cisplatin, gemcitabine; PS, performance status.

If there is a contraindication to immunotherapy, chemotherapy can be used. Vinflunine should be used for this, since a phase III study showed an overall survival advantage (OS ["overall survival"] 6.9 months) with a response rate of $9 \%$ compared to "best supportive care" (Bellmunt, 2009). Alternatively, taxane-based chemotherapy can be used, possibly in combination with gemcitabine. If first-line chemotherapy with cisplatin has shown a good response with a progres- 


\section{Natural History of Prostate Cancer in 2010}

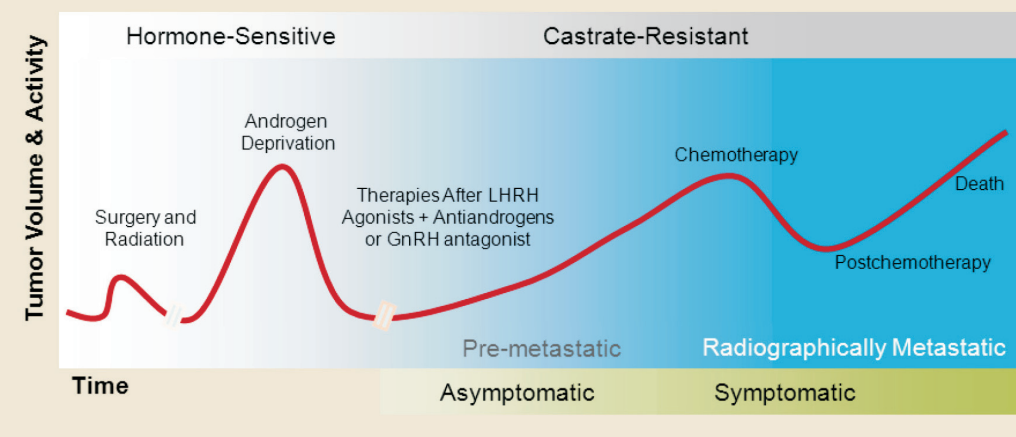

Fig. 2. The clinical course of a patient with prostate cancer and adapted therapy is shown in simplified form. LHRH, luteinising hormone releasing hormone; GnRH, gonadotrophin releasing hormone. sion-free interval 6 months and good tolerability, a cisplatin-based combination therapy can be repeated (Witjes et al., 2020).

With the exception of the vinflunine study, the data available for second-line chemotherapy is very heterogeneous with low levels of evidence, so that its use should be decided on a case-by-case basis on the basis of the general condition of the patient and the expected effectiveness and toxicity (Bellmunt, 2009).

Immunotherapy is currently being investigated as a monotherapy and in combination in studies perioperatively for cystectomy and as first-line therapy for metastatic bladder carcinoma. It therefore remains a matter of time to determine whether the so far golden standard supposed cisplatinbased chemotherapy as basic therapy alone for metastatic urothelial cancer of bladder will further retain its reigning role (Witjes et al., 2020).

\section{ROLE OF CHECKPOINT BLOCKADE IN META- STATIC PROSTATE CANCER}

In Figure 2, the clinical course of a patient with prostate cancer is shown in simplified form. It shows that the diagnosis of the disease can also be made at a later stage of the disease than the primarily non-metastatic stage. The practice-relevant details of system therapy for prostate cancer are explained in the uroweb.eu prostate-cancer guideline version from 2020 (Mottet et al., 2020).

\section{THERAPY OF HORMONE-SENSITIVE METASTATIC PROSTATE CANCER}

Furthermore, androgen deprivation is recommended to patients in this phase of the disease. It is important to ensure that the patient is informed that this is palliative therapy, that the quality of life can deteriorate under androgen deprivation and that undesirable side effects can occur (Mottet et al., 2020). The background to the recommendation for an- drogen deprivation is evidence for extension of progressionfree survival, although this was only demonstrated for the immediate use of hormone ablation (Nair et al., 2002).

A new recommendation is that, in the case of initial diagnosis at the hormone-sensitive metastatic stage of disease, patients with a good general condition (ECOG 0-1, Eastern Cooperative Oncology Group) can be offered chemotherapy with docetaxel or further hormone manipulation by abiraterone plus prednisone in addition to androgen deprivation. The basis for the possibility of combining androgen deprivation with six courses of docetaxel chemotherapy at the 75 $\mathrm{mg} / \mathrm{m} 2$ body surface area (KOF) regimen was the publications of the CHAARTED and STAMPEDE trials, which demonstrated an overall survival prolongation of 15 and 13.6 months, respectively, with combination therapy compared with androgen deprivation alone (Sweeney, 2015; James, 2016). A subgroup analysis of the CHAARTED data demonstrated that only patients with a high tumour burden defined as the presence of visceral metastases or $>4$ bone metastases outside the pelvis benefit from therapy (Sweeney, 2015).

In two large randomised prospective trials, the efficacy of the cyproterone acetate 17 inhibitor abiraterone in combination with androgen deprivation was analysed (LATITUDE, STAMPEDE) (Fizazi, 2017; James (2017). The study inclusion criteria differed in that only patients with at least two risk factors, defined as the presence of Gleason score 8 or higher, at least three bone metastases, or visceral metastases, were eligible to participate in the LATITUDE trial. Both trials demonstrated an increase in overall survival with combination therapy, with progression-free survival of 33.0 months in the combination arm vs. 14.8 months in the androgen deprivation therapy (ADT) arm. In the LATITUDE trial this difference was more clearly discriminable than in the STAMPEDE trial (43.9 vs. 30.0 months). Also, the recommendation for combining abiraterone with ADT applies only to immediate use, as no prospective randomised trials are available for later therapy (Fizazi, 2017; James, 2017). 


\section{THERAPY OF CACTRATION-RESISTANT PROSTATE CANCER}

The following therapies, in addition to ADT, can be optionally considered for patients with metastatic asymptomatic or mildly symptomatic and progressive disease: abiraterone, enzalutamide, or docetaxel. The basis for recommending therapy with abiraterone as extragonadal hormone suppression is the data from the COU-AA-302 trial, which demonstrated a survival benefit in overall survival of 34.7 vs. 30.3 months for the combination of abiraterone with prednisone compared with a placebo with prednisone in this phase of disease, respectively (Ryan, 2015). Serious side effects with therapy include occurrence of heart disease, elevated ALT (alanine aminotransferase) levels, and hypertension, and common side effects include urinary tract infections, hypokalemia, peripheral edema, and hepatotoxicity (Ryan, 2015). Enzalutamide is an androgen receptor inhibitor and blocks the shift of the androgen receptor into the nucleus as well as DNA binding. The prospective randomised PREVAIL trial comparing enzalutamide with a placebo demonstrated a survival benefit of 32.4 months in the enzalutamide group versus 30.2 months in the placebo group (Beer, 2014). Furthermore, it showed a significant prolongation of time to chemotherapy use, to a relevant bone event, and to PSA (prostate specific antigen) progression. Only patients in good general health were included in this study (ECOG 0-1) and relevant side effects include memory impairment, hypertension and fatigue. Furthermore, increased interactions with CYP2C8 and CYP3A4 inhibitors and inducers are observed when enzalutamide is taken, which absolutely requires appropriate monitoring of the corresponding comedication. Abiraterone or enzalutamide is approved for asymptomatic or mildly symptomatic patients with castrationresistant prostate cancer after failure of hormone deprivation, in whom chemotherapy is not yet indicated (Mottet et al., 2020).

The approval for chemotherapy with docetaxel in combination with prednisone for the treatment of patients with metastatic castration-resistant prostate cancer is based on data from the TAX-327 trial, which demonstrated a 2.9-month survival benefit of docetaxel therapy over therapy with prednisone (Grance et al., 2019). Relevant side effects that patients need to be informed about before starting therapy include alopecia, fatigue, nausea, neutropenia, diarrhea, nail changes, and peripheral neuropathy, which may persist. Particular emphasis should be placed on performing a geriatric assessment in patients over 70 years of age prior to initiation of therapy to better assess the risk of therapy-related grade 3 to 5 adverse events (Balar, 2017). As a study demonstrated similar efficacy of therapy with docetaxel 50 $\mathrm{mg} / \mathrm{m} 2$ KOF every two weeks with fewer side effects than the three-week regimen of $75 \mathrm{mg} / \mathrm{m} 2 \mathrm{KOF}$, patients may also be offered the two-week regimen in this phase of the disease (Bellmunt, 2017).

The radionuclide radium-223 represents a first- and secondline treatment option in patients with androgen-independent, symptomatic, and progressive disease and symptomatic osseous metastases without concurrent visceral metastases. The background for approval is the demonstration of a survival benefit of 14.9 months in the treatment arm versus 11.3 months in the placebo arm of the prospective randomised ALSYMPCA trial, in which approximately $43 \%$ of patients in both groups were not pretreated with docetaxel (Sharma, 2017). In addition, a prolongation of the time to a skeletal event and to a PSA rise might occur. Neutropenias, thrombocytopenias, diarrhea, vomiting, and nausea should be noted as potential side effects (Mottet et al., 2020).

In the situation of castration-resistant progressive prostate carcinoma after docetaxel chemotherapy with good general condition of the patient, the following therapeutic options are available in combination with symptom-related supportive therapy: abiraterone in combination with prednisone, enzalutamide, cabazitaxel, and radiotherapy with radium223. The approval of cabazitaxel was based on data from a randomised trial testing cabazitaxel at a dose of $25 \mathrm{mg} / \mathrm{m} 2$ KOF with prednisone after docetaxel chemotherapy against mitoxantrone with prednisone. Only patients in good general health (ECOG 0-1) were included in this study, and therapy with cabazitaxel was shown to prolong survival by a median of 2.4 months and prolong progression-free survival by 1.4 months (Heidenreich, 2013). Continuous blood count monitoring is important during use, as febrile neutropenia can occur with therapy, and further haematuria, diarrhea, and fatigue are observed, which occur less frequently at the $20 \mathrm{mg} / \mathrm{m} 2 \mathrm{KOF}$ dose with equal efficacy to the higher dose (Eisenberger, 2017).

The radionuclide 177Lu-PSMA (prostate specific membrane antigen) represents an interesting approach for the therapy of patients after docetaxel chemotherapy. Since the drug is not yet approved, a therapy trial should only take place after presentation in an interdisciplinary tumour conference and the patient must be informed that it is an individual therapy trial. The data available to date are heterogeneous, but in the case series to date, a drop in PSA is described in approximately $50 \%$ of patients (Calopedos et al., 2017).

Therapy of symptomatic bone metastases includes pain therapy, the option of local radiation and/or surgical intervention, possibly in combination with radiation (Falkmer $e t$ al., 2003). Regarding the use of bisphosphonates for the prevention of bone events in patients with hormonesensitive prostate carcinoma and proven bone metastases, the guideline group opposed the use of these substances in this indication because the benefit of administering bisphosphonates was insufficient. For the RANK ligand ("receptor activator of NF kappa-B") denosumab, there is no clear study situation for a corresponding recommendation. In contrast, the potential side effects of treatment such as osteonecrosis of the jaw and impaired renal function outweigh the side effects of bisphosphonates, and osteonecrosis of the jaw and hypocalcemia outweigh the side effects of denosumab. In the therapy of bone metastases in patients with androgen-independent carcinoma, both substance groups for delaying skeletal events have been left as optional therapy 
recommendations (Mottet et al., 2020; Falkmer et al., 2003).

The PROSPER trial tested the use of enzalutamide in combination with ADT compared with a placebo and ADT in patients with asymptomatic castration-resistant nonmetastatic prostate cancer and a PSA doubling time less than ten months (Hussain, 2018). Because of the fact that therapy with enzalutamide was shown to prolong metastasis-free survival by 36.6 months versus 14.7 months and to prolong the interval to other antineoplastic therapy by 39.6 months versus 17.7 months, enzalutamide was subsequently approved for this indication in the United States and also in Europe (Hussain, 2018). The 2019 ENZAMET trial tested the use of enzalutamide in combination with androgen deprivation against nonsteroidal androgen receptor blockade in combination with ADT. An improvement in overall survival, prolongation of progression-free survival, and clinical progression-free survival was presented with the use of enzalutamide, and approval for enzalutamide in the indication for First-Line Therapy in Metastatic Prostate Cancer has been submitted (Davis, 2019).

Apalutamide is a non-steroidal androgen receptor blocker that was evaluated in the SPARTAN trial in patients with non-metastatic castration-resistant prostate cancer and a PSA doubling time less than ten months in combination with ADT versus placebo in combination with hormone deprivation therapy. The trial showed a prolongation of metastasis-free survival of 40.5 months compared with 16.2 months in the placebo group, as well as an improvement in secondary endpoints such as progression-free survival and time to symptomatic progression (Smith, 2018). In the TITAN trial, the use of apalutamide in combination with ADT vs. placebo in combination with ADT was prospectively analysed in a randomised fashion in patients with metastatic hormone-sensitive prostate cancer. This trial showed an advantage in the apalutamide group in terms of progressionfree survival as well as overall survival (Chi, 2019). The most frequent side effects observed with apalutamide were skin rashes and hypothyroidism. Apalutamide is approved in patients with metastatic hormone-sensitive and in patients with non-metastatic castration-resistant prostate cancer (Mottet et al., 2020).

\section{ROLE OF CHECKPOINT BLOCKADE IN META- STATIC KIDNEY CLEAR CELL CARCINOMA, BACK- GROUND AND THE OVERVIEW OF THERAPY}

At the beginning of 2020, apart from the cytokines interferon- $\alpha$ and interleukin-2, which have been known for many years, but whose value is highly limited, a total of 14 different treatment options are available for the therapy of advanced/metastatic renal cell carcinoma (see chronological therapy landscape in Figure 3).

These include tyrosine kinase inhibitors (axitinib, cabozantinib, lenvatinib in combination with everolimus, pazopanib, sorafenib, sunitinib, tivozanib), mTOR inhibitors ("mechanistic target of rapamycin": everolimus, temsirolimus), VEGF antibodies ("vascular endothelial growth factor": bevacizumab in combination with interferon- $\alpha$ ), PD-1 inhibitors [pembrolizumab in combination with axitinib, nivolumab in combination with ipilimumab (first-line) or alone (second-line)], PD-L1 inhibitors (avelumab in combination with axitinib (first-line), and CTLA-4 inhibitors ("cytotoxic t-lymphocyte antigen": ipilimumab in combination with nivolumab (first-line) (Ljungberg et al., 2020).

The decision for a certain therapy is mainly based on the parameter named adequate prognosis group (called MSKCC score or Motzer score or International Metastatic Renal Cell Carcinoma Database Consortium (IMDC), also called IMDC score or Heng score) and the current line of therapy. The MSKCC score considers the parameters of general condition, time from diagnosis to therapy (of metastases), laboratory parameters: haemoglobin, lactate dehydrogenase, and corrected calcium, and scores one point for each abnormal result. Good, intermediate, and poor prognosis (in terms of OS) are assumed at 0 points, $1-2$ points, and $\geq 3$ points, respectively. In the IMDC score, the parameters of general condition, time from diagnosis to therapy (of metastases), laboratory parameters (haemoglobin, corrected calcium, neutrophil granulocytes, and platelets) are considered and one point is given for each abnormal result.

Good, intermediate, and poor prognosis (in terms of OS) is assumed at 0 points, $1-2$ points, and $\geq 3$ points, respectively. Studies in recent years have used the above scores

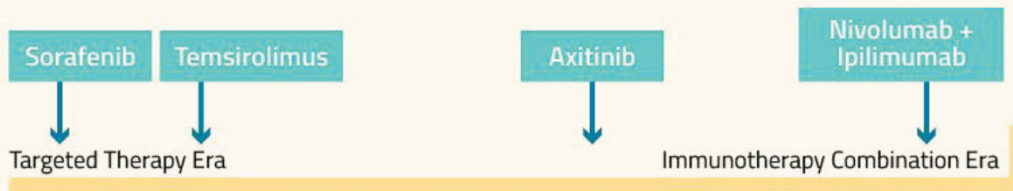

200520062007200820092010201120122013201420152016201720182019

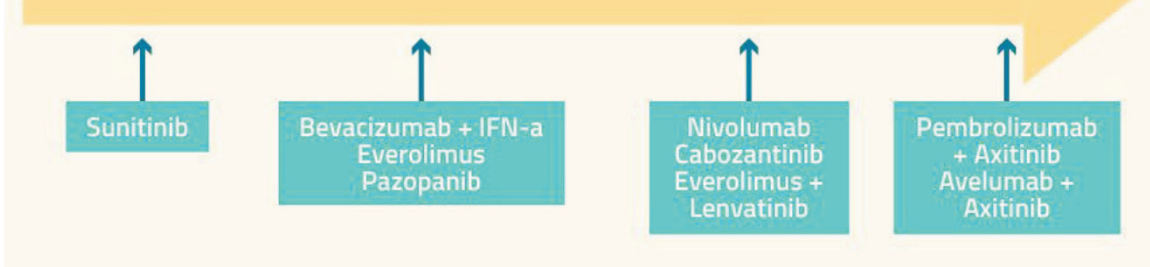

Fig. 3. Therapy landscape for metastatic clear cell renal cell carcinoma. 
and also the respective risk groups in different ways, especially in the way to choose the most appropriate treatment setting (Ljungberg et al., 2020).

\section{TREATMENT ALGORITHMS FOR PATIENTS WITH METASTATIC RENAL CLEAR CELL CARCINOMA}

In patients with metastatic clear cell renal carcinoma (approximately $80 \%$ of all patients with renal cell carcinoma), the history regarding previous tumour diagnostics and tumour therapy must first be understood.

Patient factors such as general condition, age, existing medication, etc., as well as tumour factors such as dynamics of the disease, symptomatology, histological subtype, metastatic burden, etc., must be ascertained (Ljungberg et al., 2020).

In the case of metastatic disease (approximately $15 \%$ of all cases), the performance of a cytoreductive nephrectomy needs to be discussed. From an oncological point of view, this question should be evaluated cautiously nowadays. However, surgery may be indicated if symptoms are present. Local metastatic therapy (surgery or percutaneous radiotherapy) may be reasonable in the presence of oligometastasis (estimated \% of all patients). Such therapy may be indicated only in the presence of adjuvant systemic therapy (Ljungberg et al., 2020).

When considering the initiation of systemic therapy, tumour dynamics is a crucial criterion.

In the absence of or low dynamics, a delayed start of therapy is quite possible (estimated \% of all patients). If the indication for therapy initiation is established, the determination of the Heng score is essential against the background of drug selection in compliance with the approval and is easy to determine using the appropriate risk assessment calculator if the relevant laboratory parameters are available (Ljungberg et al., 2020).

For first-line therapy in patients with advanced and/or metastatic renal clear cell carcinoma and good prognosis (about $20 \%$ of all cases), pembrolizumab in combination with axitinib should be used according to the recommendations of actual European guidelines for renal cell carcinoma (see
Fig. 4). Alternatively, bevacizumab + interferon- $\alpha$, pazopanib, sunitinib, or tivozanib (named in alphabetical order) can be used.

The choice of systemic therapy should be individualised based on the expected efficacy, toxicity spectrum, and comorbidity of the patient. In asymptomatic patients with a favourable prognosis, targeted systemic therapy can also be initiated, postponed or only when progression is proven and local therapy options are not available (active surveillance) (Ljungberg et al., 2020).

For first-line therapy in patients with advanced and/or metastatic clear cell renal cell carcinoma and intermediate or poor prognosis (approximately $60 \%$ and $20 \%$ of all cases, respectively), nivolumab in combination with ipilimumab or pembrolizumab in combination with axitinib should be used according to the recommendations of actual European guidelines for renal cell carcinoma (see Fig. 4) (Ljungberg et al., 2020). Alternatively, cabozantinib should be used. In patients with poor prognosis, temsirolimus can also be used. In asymptomatic patients with intermediate prognosis, targeted systemic therapy can also be initiated, postponed or only when progression is proven and local therapy options are not available (active surveillance) (Ljungberg et al., 2020).

For second-line therapy, decisions are no longer made according to the prognosis score, but according to the type of prior therapy (Fig. 4).

According to the recommendations of actual European guidelines for renal cell carcinoma, no standard has been established for patients with advanced and/or metastatic clear cell renal cell carcinoma after CPI-based (checkpoint inhibitor) combination therapy (Ljungberg et al., 2020). Nevertheless, a tyrosine kinase inhibitor (TKI) should be administered in these patients. In patients with prior VEGF-targeted therapy alone, follow-up therapy should consist of cabozantinib or nivolumab. A specific sequence of agents cannot be recommended. Alternatively, the combination of lenvatinib and everolimus can be used (Ljungberg et al., 2020).

No standard has been established for third-line therapy according to the recommendations of actual European guidelines for renal cell carcinoma. The selection of system ther-
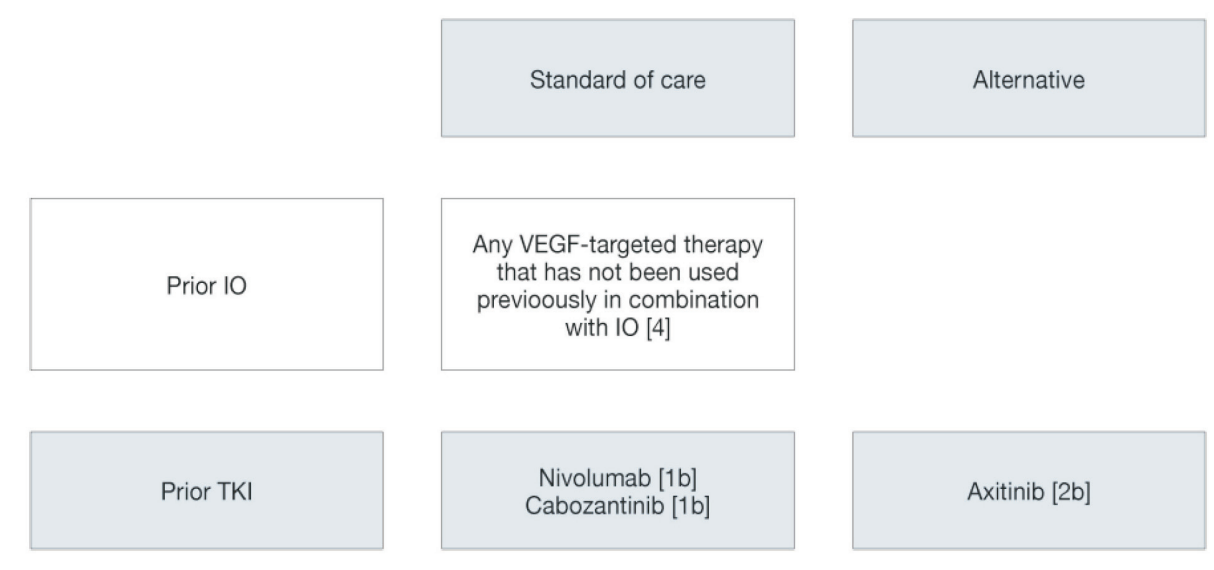

Fig. 4. Guidelines Recommendations for later-line therapy in clear-cell metastatic renal cancer. IMDC, The International Metastatic Renal Cell Carcinoma Database Consortium; IO, immunotherapy; TKI, tyrosine kinase inhibitors; VEGF, vascular endothelial growth factor; [1b], based on one randomised controlled phase III trial; [2b], subgroup analysis of a randomised controlled phase III trial; [4], expert opinion. 


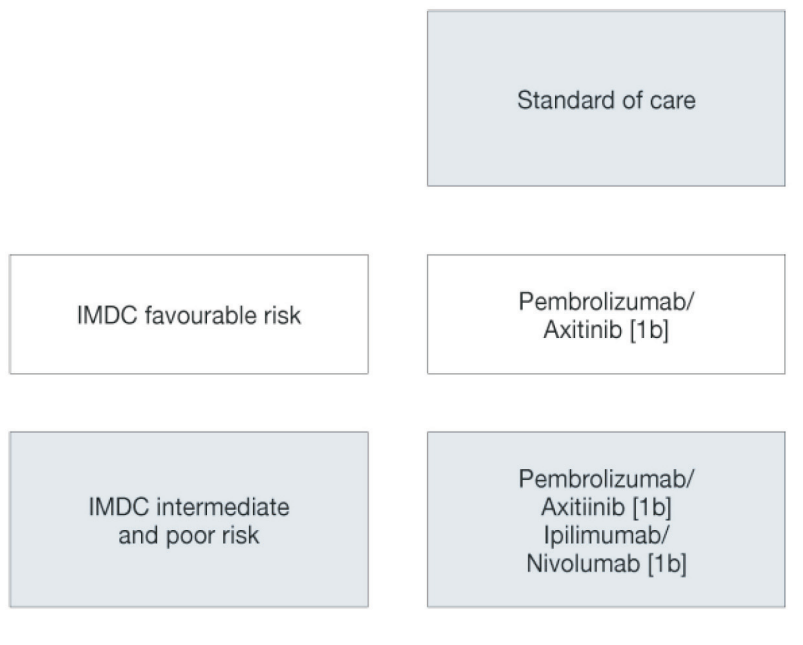

apy should take into account the previous therapy and substances should be given that were not included in the previous therapy (Ljungberg et al., 2020).

The treatment algorithm for metastatic clear cell renal cell carcinoma includes active surveillance, local metastatic therapy, and systems therapy.

In 2015/2016, significant changes were seen, particularly in the second-line setting. Notable among these were the new agents nivolumab, cabozantinib and lenvatinib in combination with everolimus (Fig. 5).

In 2017, cabozantinib as well as the combination of nivolumab and ipilimumab showed an advantage over sunitinib.

In 2019, three combination therapies (nivolumab plus ipilimumab, pembrolizumab plus axitinib, and avelumab plus axitinib, each tested against sunitinib) were approved for the treatment of metastatic renal cell carcinoma with intermediate/poor prognosis or across all three prognosis groups. Combination therapy represents the new standard of care in this regard (Fig. 4).

Future activities must continue to provide answers to the following issues: patient selection, biomarkers, assessment of treatment response, and side effect management (Ljungberg et al., 2020).

\section{CONCLUSION}

An immune checkpoint inhibitor is a collective name used to describe molecules from a drug class that targets adaptive immune suppression pathways. These molecules block inhibitory immune checkpoints, which are often used by cancers to build up protection against organism adaptive immunity. Being a landmark achievement of modern medicine, checkpoint inhibitors are now used for personalised treatment of urinary bladder, prostate cancer and kidney clear cell carcinoma.

Finding a predictive biomarker of outcome for immune check point inhibitors has been a hot topic of research for the last few years. As a result, today there is a wide variety of such biomarkers of different types. There is evidence in
Alternative in patients who can not receive or tolerate immune checkpoint inhibitors
Sunitinib $[1 b]$
Pazopanib* $[1 b]$

Cabozantinib [2a

Sunitinib 1 b]

Pazopanib* [1b]
Fig. 5. Updated European Association of Urology Guidelines recommendations for the treatment of first-line and following lines in clear-cell metastatic renal cancer. IMDC, The International Metastatic Renal Cell Carcinoma Database Consortium; * pazopanib for intermediate-risk disease only; [1b], based on one randomised controlled phase III trial; [2a], based on one randomised controlled phase II trial. support of predictive biomarkers based on programmed death-ligand 1 (PD-L1)/ programmed cell death-1 (PD-1) expression, mismatch repair deficiency (dMMR), and microsatellite instability-high (MSI-H), tumour mutational burden (TMB), gene signatures, tumour-infiltrating lymphocytes (TILs) counts, peripheral blood lymphocyte count (Filipovic, 2020).

Today only two predictive biomarkers are approved to guide decision making about prescription of checkpoint inhibitors: expression of PD-L1 and MSI-H/dMMR.

However, patients with PD-L1 negativity and wild type of mismatch repair proteins also benefit from the treatment.

Therefore, further studies are urgently needed to discover potentially relevant biomarkers that could stratify patients and predict the benefit and effectiveness of checkpoint inhibitors for the treatment of urinary bladder, prostate cancer and kidney clear cell carcinoma.

\section{REFERENCES}

Balar, A. V. (2017). Atezolizumab as first-line treatment in cisplatin-ineligible patients with locally advanced and metastatic urothelial carcinoma: A single-arm, multicentre, phase 2 trial. Lancet, 389, 67-76.

Balar, A. V. (2017). First-line pembrolizumab in cisplatin-ineligible patients with locally advanced and unresectable or metastatic urothelial cancer (KEYNOTE-052): A multicentre, single-arm, phase 2 study. Lancet Oncol., 18, 1483-1492.

Beer, T. M. (2014). Enzalutamide in metastatic prostate cancer before chemotherapy. New Engl. J. Med., 371, 424-433

Bellmunt, J. (2017). Pembrolizumab as second-line therapy for advanced urothelial carcinoma. New Engl. J. Med., 376, 1015-1026.

Bellmunt, J. (2009). Phase III trial of vinflunine plus best supportive care compared with best supportive care alone after a platinum-containing regimen in patients with advanced transitional cell carcinoma of the urothelial tract. J. Clin. Oncol. Off. J. Amer. Soc. Clin. Oncol., 27, 4454-4461.

Butte, M. J., Keir, M. E., Phamduy, T. B., Sharpe, A. H., Freeman, G. J. (2007). Programmed death-1 ligand 1 interacts specifically with the B7-1 costimulatory molecule to inhibit $\mathrm{T}$ cell responses. Immunity, 27 (1), 111-122.

Calopedos, R. J. S., Chalasani, V., Asher, R., Emmett, L., Woo, H. H. (2017). Lutetium-177-labelled anti-prostate-specific membrane antigen antibody and ligands for the treatment of metastatic castrate-resistant prostate cancer: A systematic review and meta-analysis. Prostate Cancer Prostatic Dis., 20, 352-360. 
Cameron, F., Whiteside, G., Perry, C. (2011). Ipilimumab: First global approval. Drugs, 71 (8), 1093-1104.

Chi, K. N. (2019). Apalutamide for metastatic, castration-sensitive prostate cancer. New Engl. J. Med., 381, 13-24.

Davis, I. D. (2019). Enzalutamide with standard first-line therapy in metastatic prostate cancer. New Engl. J. Med., 381, 121-131.

Devlin, H. (2018). James P Allison and Tasuku Honjo win Nobel prize for medicine. The Guardian. https://www.theguardian.com/science/2018/oct/ 01/james-p-allison-and-tasuku-honjo-win-nobel-prize-for-medicine (accessed 25.04.2021).

Eisenberger, M. (2017). Phase III study comparing a reduced dose of cabazitaxel $(20 \mathrm{mg} / \mathrm{m}(2))$ and the currently approved dose $(25 \mathrm{mg} / \mathrm{m}(2))$ in postdocetaxel patients with metastatic castration-resistant prostate cancer-PROSELICA. J. Clin. Oncol. Off. J. Amer. Soc. Clin. Oncol., 35, 3198-3206.

Eisenhardt, A., Ohlmann, C. H., Doehn, C. (2020). Algorithmen zur Systemtherapie bei Prostata-, Urothel- und Nierenzellkarzinom. Der Urologe, 59, 533-543 (in German).

Falkmer, U., Jarhult, J., Wersall, P., Cavallin-Stahl, E. (2003). A systematic overview of radiation therapy effects in skeletal metastases. Acta Oncol., 42 (5-6), 620-633.

Filipovic, A., Miller, G., Bolen, J. (2020). Progress toward identifying exact proxies for predicting response to immunotherapies. Front Cell Dev. Biol., 17 (8), 155.

Fizazi, K. (2017). Abiraterone plus prednisone in metastatic, castration-sensitive prostate cancer. New Engl. J. Med., 377, 352-360.

George, D. J. (2013). Metastatic castrate resistant prostate cancer management metastatic CRPC: A cross-sectional landscape of the disease and treatments. Urology, 82, http://webedcafe.com/extern/program_me$\mathrm{dia} /$ goldjournal.net/2013/prostate_cancer/figure.php?speaker=george $\&$ figure $=1$ (accessed 25.04.2021).

Grance, E., Galsky, M., Arrenz, J. A., De Santis, M., Davis, I. D., De Giorgi, U. F. F., Mencinger, M., Kikuchi, E., Garcia del Muro, X., Gumus, M., Ozguroglu, M., Rezazadeh Kalebasty, A., Park., S. H., Alekseev, B. Y., Schutz, F. A. B., Li, J. R., Mecke, A., Mariathasan, S., Thastrom, A., Bamias, A. (2019). LBA14_PRIMvigor130: Efficacy and safety from a phase III study of atezolizumab (atezo) as monotherapy or combined with platinum-based chemotherapy (PBC) vs placebo + PBC in previously untreated locally advanced or metastatic urothelial carcinoma (mUC). Ann. Oncol., 30 (5), v888-v889.

Heidenreich, A. (2013). Cabazitaxel plus prednisone for metastatic castration-resistant prostate cancer progressing after docetaxel: Results from the German compassionate-use programme. Eur. Urol., 63, 977-982.

Hussain, M. (2018). Enzalutamide in men with nonmetastatic, castration-resistant prostate cancer. New Engl. J. Med., 378, 2465-2474.

James, N. D. (2017). Abiraterone for prostate pancer not previously treated with hormone therapy. New Engl. J. Med., 377, 338-351.

James, N. D. (2016). Addition of docetaxel, zoledronic acid, or both to first-line long-term hormone therapy in prostate cancer (STAMPEDE):
Survival results from an adaptive, multiarm, multistage, platform randomised controlled trial. Lancet, 387, 1163-1177.

Karwacz, K., Bricogne, C., MacDonald, D., Arce, F., Bennett, C. L., Collins, M., Escors, D. (2011). PD-L1 co-stimulation contributes to ligand-induced $\mathrm{T}$ cell receptor down-modulation on CD8+ T cells. EMBO Mol. Med., 3 (10), 581-592.

Klaassen, Z., Wallis, C. J. D. (2020). First line therapy for metastatic clear cell renal cell carcinoma. Kidney-cancer-today/ 118209-first-line-therapyfor-metastatic-clear-cell-rcc.html (accessed 24.04.2021).

Ljungberg, B., Albiges, L., Bensalah, K., Bex, A., Giles, R.H., Hora, M., Kuczyk, M.A., Lam, T., Marconi, L., Merseburger, A. S., Powles, T., Staehler, M., Volpe, A. (2020). EAU Guidelines on Renal Cell Carcinoma. https://uroweb.org/wp-content/uploads/EAU-Guidelines-on-Renal-Cell-C arcinoma-2020.pdf (accessed 24.04.2021).

Maase, H. (2005). Long-term survival results of a randomized trial comparing gemcitabine plus cisplatin, with methotrexate, vinblastine, doxorubicin, plus cisplatin in patients with bladder cancer. J. Clin. Oncol. Off. J. Amer. Soc. Clin. Oncol., 23, 4602-4608.

Mottet, N., Cornford, P., van den Bergh, R. C. N., De Santis, M., Fanti, S., Gillessen, S., Grummet, J., Henry, A. M., Lam, T. B., Mason, M. D., van der Kwast, T. H., van der Poel, H. G., Rouviere, O., Schoots, I. G., Tilki, D., Wiegel, T. (2020) Oncology Guidelines on Prostate Cancer. https://uroweb.org/guideline/prostate-cancer/ (accessed 24.04.2021).

Nair, B., Wilt, T., MacDonald, R., Rutks, I. (2002). Early versus deferred androgen suppression in the treatment of advanced prostatic cancer. Cochrane Database Syst. Rev., (1), CD003506.

Pardoll, D. M. (2012). The blockade of immune checkpoints in cancer immunotherapy. Nature Rev. Cancer. 12 (4), 252-264.

Ryan, C. J. (2015). Abiraterone acetate plus prednisone versus placebo plus prednisone in chemotherapy-naive men with metastatic castration-resistant prostate cancer (COU-AA-302): Final overall survival analysis of a randomised, double-blind, placebo-controlled phase 3 study. Lancet Oncol., 16, 152-160.

Sharma, P. (2017). Nivolumab in metastatic urothelial carcinoma after platinum therapy (CheckMate 275): A multicentre, single-arm, phase 2 trial. Lancet Oncol., 18, 312-322.

Smith, M. R. (2018). Apalutamide treatment and metastasis-free survival in prostate cancer. New Engl. J. Med., 378, 1408-1418.

Sweeney, C. J. (2015). Chemohormonal therapy in metastatic hormone-sensitive prostate cancer. New Engl. J. Med., 373, 737-746.

Syn, N. L., Teng, M. W. L., Mok, T. S. K. Soo, R. A. (2017). De-novo and acquired resistance to immune checkpoint targeting. The Lancet Oncology, 18 (12), e731-e741.

Witjes, J. A., Bruins, H. M., Cathomas, R., Comperat, E., Cowan, N. C., Gakis, G., Hernandez, V., Lorch, A., Ribal, M. J., Thalmann, G. N., van der Heijden, A. G., Veskimae, E. (2020). EAU Guidelines on muscle-invasive and metastatic bladder cancer. https://uroweb.org/guideline/bladder-cancer-muscle-invasive-and-metastatic/ (accessed 24.04.2021).

Received 12 January 2021

Accepted in the final form 2 March 2021

\section{"JAUNI BĒRNI SMILŠUKASTĒ" — SPĒLES MAINĪTĀJI. IMŪNTERAPIJAS LOMA PERSONALIZĒTĀ PROSTATAS, UROTELIĀLĀ UN NIERU KARCINOMAS ĀRSTĒŠANĀ}

Agrīna vēža atklāšana, diagnosticēšana un personalizēta pieeja ārstēšanai ir galvenais atslēgas punkts veiksmīgam iznākumam un var glābt dzīvības. Tas vienmēr ir bijis svarīgs jautājums gan medicīnas, gan sociālajā jomā. Jaunu agrīnas stadijas vēža diagnostikas rīku meklěšana ir ḷāvusi apsvērt iespēju izmantot dažādas pieejas, piemēram, izelpoto gaisu, biomarkierus asinīs, urīna testus, kā arī attēlveidošanas paṇēmienus. Šo laiku un visu, kas notiek mums apkārt, varētu raksturot kā dīvainu un ḷoti neparastu. Šo salīdzinājumu var lietot ne tikai koronavīrusa aktuālās situācijas laikā, bet arī personalizētajā medicīnā 21. gadsimta otrajā dekādē. Šajā gadījumā — kontrolpunktu inhibitoru atklāšanā. Vecās dogmas, piemēram, kịmijterapija un metastāžu kirurğija tiek papildinātas ar jauniem kontrolpunktu inhibitoru diagnostikas un terapijas veidiem. Mūsu pētījuma grupa sniedz īsu un detalizētu, uz vadlīnijām balstītu izklāstu par to, kas ir kontrolpunktu blokāde un kā tā darbojas trīs audzēju veidiem — urīnpūšla, prostatas un nieru vēžos. Ši pārskata mērḳis ir demonstrēt aktuālo imūnsistēmas terapijas nozīmi kā potenciālu ārstēšanas veidu prostatas, urīnpūšḷ un nieru vēža gadījumos. 